University of Nebraska - Lincoln

DigitalCommons@University of Nebraska - Lincoln

USDA National Wildlife Research Center - Staff Publications
U.S. Department of Agriculture: Animal and Plant Health Inspection Service

October 2003

\title{
EFFECTS OF RADIO-TRANSMITTERS ON FECAL GLUCOCORTICOID LEVELS IN CAPTIVE DICKCISSELS
}

\author{
Kimberly M. Suedkamp Wells \\ University of Missouri-Columbia \\ Brian E. Washburn \\ University of Missouri-Columbia, brian.e.washburn@aphis.usda.gov \\ Joshua J. Millspaugh \\ University of Missouri-Columbia \\ Mark R. Ryan \\ University of Missouri-Columbia \\ Michael W. Hubbard \\ Missouri Department of Conservation
}

Follow this and additional works at: https://digitalcommons.unl.edu/icwdm_usdanwrc

Part of the Environmental Sciences Commons

Suedkamp Wells, Kimberly M.; Washburn, Brian E.; Millspaugh, Joshua J.; Ryan, Mark R.; and Hubbard, Michael W., "EFFECTS OF RADIO-TRANSMITTERS ON FECAL GLUCOCORTICOID LEVELS IN CAPTIVE DICKCISSELS" (2003). USDA National Wildlife Research Center - Staff Publications. 523.

https://digitalcommons.unl.edu/icwdm_usdanwrc/523

This Article is brought to you for free and open access by the U.S. Department of Agriculture: Animal and Plant Health Inspection Service at DigitalCommons@University of Nebraska - Lincoln. It has been accepted for inclusion in USDA National Wildlife Research Center - Staff Publications by an authorized administrator of DigitalCommons@University of Nebraska - Lincoln. 


\title{
SHORT COMMUNICATIONS
}

The Condor 105:805-810

(C) The Cooper Ornithological Society 2003

\section{EFFECTS OF RADIO-TRANSMITTERS ON FECAL GLUCOCORTICOID LEVELS IN CAPTIVE DICKCISSELS}

\author{
Kimberly M. Suedkamp Wells ${ }^{1,3}$, Brian E. Washburn ${ }^{1,4}$, Joshua J. Millspaugh ${ }^{1}$, Mark R. Ryan ${ }^{1}$ and \\ MichaEl W. HubBaRD ${ }^{2}$ \\ ${ }^{1}$ Department of Fisheries and Wildlife Sciences, University of Missouri-Columbia, \\ 302 ABNR Building, Columbia, MO 65211 \\ ${ }^{2}$ Missouri Department of Conservation, 1110 South College, Columbia, MO 65211
}

Abstract. We determined the effects of a leg-harness transmitter on fecal glucocorticoid levels of wild male Dickcissels (Spiza americana) in captivity. During the postbreeding season of 2001, we captured 10 male Dickcissels in central Missouri and housed them in individual pens of an outdoor aviary. We radiotagged five birds; the other five were captured and handled, but were not radio-tagged. We collected fecal samples every other day prior to attachment (31 July21 August) and after attachment (24 August-20 September). Body condition and morphology were similar between control and transmitter-equipped birds. We observed a significant interaction between transmitter attachment and time since attachment. Compared to baseline levels, fecal glucocorticoid metabolites were significantly lower in control $\left(6.1 \pm 13.7 \mathrm{ng} \mathrm{g}^{-1}\right)$ than transmitter-equipped $\left(102.3 \pm 13.7 \mathrm{ng} \mathrm{g}^{-1}\right)$ birds during the first $24 \mathrm{hr}$ after attachment. Although transmitter-equipped birds showed elevated fecal glucocorticoid levels, the response was acute and returned to baseline levels within $48 \mathrm{hr}$.

Key words: Dickcissel, fecal glucocorticoids, passerines, Spiza americana, stress, transmitter.

Efecto de los Radiotransmisores en los Niveles de Glucocorticoides Fecales en Individuos Cautivos de Spiza americana

Resumen. Determinamos los efectos de poner un transmisor con arnés de pata en los niveles de glucocorticoides fecales de machos silvestres de Spiza ame-

Manuscript received 8 August 2002; accepted 28 May 2003.

${ }^{3}$ E-mail: kmsnq6@mizzou.edu

${ }^{4}$ Present address: United States Department of Agriculture, Animal and Plant Health Inspection Service, 6100 Columbus Avenue, Sandusky, OH 44870. ricana en cautiverio. Durante la temporada post-reproductiva de 2001, capturamos 10 individuos de $S$. americana en la parte central de Missouri y hospedamos estas aves en jaulas individuales que formaban parte de un aviario al aire libre. Pusimos radio-transmisores en sólo cinco de estos pájaros, los otros cinco sólo fueron capturados y manipulados. Colectamos muestras fecales en días alternados antes (31 julio-21 agosto) y después (24 agosto-20 septiembre) de poner los transmisores. La condición corporal y morfología fueron similares entre individuos con transmisor y individuos control. Observamos una interacción significativa entre poner los transmisores y el tiempo desde que fueron puestos. Comparados con niveles iniciales, hubo diferencias significativas en los metabolitos de los glucocorticoides fecales entre los pájaros control $\left(6.1 \pm 13.7 \mathrm{ng} \mathrm{g}^{-1}\right)$ y con transmisores $(102.3 \pm 13.7$

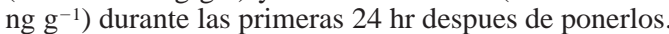
Aunque los pájaros con transmisores mostraron niveles elevados de glucocorticoides fecales, la respuesta aguda regresó a niveles iniciales en menos de $48 \mathrm{hr}$.

Radio-telemetry is commonly used for evaluating animal space use and movements (Kernohan et al. 2001), and its use has increased in ornithological field studies (Sykes et al. 1990, Rappole and Tipton 1991). However, one assumption associated with this technique is that animals with transmitters behave similarly to animals without transmitters (White and Garrott 1990). Many researchers assume that transmitter effects are negligible without explicitly evaluating potential adverse effects. In a review of major journals, Withey et al. (2001) found 96 articles that studied transmitter effects on animals. Although birds were the largest group represented (79\%), only four passerine studies were documented. From the limited research on passerines, effects of transmitters include shortened migration ranges (Powell et al. 1998), fewer foraging bouts (Brigham 1989), weight loss (Sykes et al. 1990), 
and altered behavior (Sykes et al. 1990). Although transmitter effects varied by attachment method (Sykes et al. 1990), all four studies concluded that radio-transmitters had minimal to negligible effects (Brigham 1989, Sykes et al. 1990, Neudorf and Pitcher 1997, Powell et al. 1998).

None of the aforementioned passerine studies addressed physiological effects. Some physiological responses, such as the stress response (i.e., increased glucocorticoid secretion) may be more complicated and subtle, and hence harder to assess, than behavioral changes. By using glucocorticoid data to identify stress responses, researchers can gain insight into potential transmitter-induced behavioral and physiological responses that compromise animal wellbeing (Sapolsky et al. 2000). To our knowledge, there is no published research examining the effects of transmitters on stress responses for passerines.

Evaluating the stress response in birds typically involves measuring plasma corticosterone, the primary stress hormone in birds (Wingfield et al. 1998). However, capturing and handling associated with blood collection can cause additional increases in glucocorticoids (LeMaho et al. 1992) and confound interpretation (Washburn et al. 2002). Recently, the use of a noninvasive technique involving fecal sample collection has been proposed to reduce stress responses associated with sampling procedures (Hiebert et al. 2000, Wasser et al. 2000). Our objective was to evaluate the effects of capture, handling, and radio-transmitter attachment on wild, male Dickcissels (Spiza americana) held in captivity using fecal glucocorticoid assays.

\section{METHODS}

\section{STUDY AREA AND BIRD CAPTURE}

We captured 10 male Dickcissels using mist nets and song playback recordings between 06:00 and 10:00 CDT between 29 June and 15 July 2001. We captured three males from Prairie Fork Conservation Area $\left(38^{\circ} 53^{\prime} \mathrm{N}, 91^{\circ} 44^{\prime} \mathrm{W}\right)$, approximately $70 \mathrm{~km}$ east of Columbia, Missouri, and seven males from Tucker Prairie $\left(38^{\circ} 57^{\prime} \mathrm{N}, 91^{\circ} 58^{\prime} \mathrm{W}\right)$ in Callaway County, central Missouri, approximately $53 \mathrm{~km}$ east of Columbia. Immediately after capture, we placed birds in portable commercial bird cages $(60 \times 45 \times 45 \mathrm{~cm})$ with food and water and transported them to the University of Missouri T. S. Baskett Wildlife Research and Education Center, approximately $5 \mathrm{~km}$ east of Ashland, Missouri. We housed birds individually in adjoining pens $(3.8 \times$ $0.6 \times 2.1 \mathrm{~m})$ in an outdoor aviary constructed of galvanized hardware cloth $(1.27 \times 1.27 \mathrm{~cm})$. We provided a birdseed mixture (sorghum grains, wheat, crimped corn, oats, and sunflower seed) and water, ad libitum. We provided one perch per pen constructed of nylon cord rope secured horizontally approximately $1.5 \mathrm{~m}$ off the ground. Below each perch, we inserted a cardboard tray covered with Saran Wrap (Dow Chemical Company, Midland, Michigan) to collect feces.

\section{EXPERIMENTAL DESIGN}

We placed birds in 10 adjacent pens, randomized the treatment (control or transmitter) assigned to the first pen, and then alternated treatments on subsequent pens. The birds were allowed to acclimate for a min- imum of two weeks prior to collecting fecal samples. From 31 July to 21 August 2001, we collected preattachment fecal samples every other day for 11, 24-hr collection periods. We collected feces on collection trays every other morning (07:00-09:00 CDT); samples consisted of all feces on plastic collection trays from the previous $24 \mathrm{hr}$. After each collection period, feces were removed from the plastic wrap and transferred to plastic 7-mL scintillation vials using a metal spatula, and frozen at $-20^{\circ} \mathrm{C}$.

At the beginning of the attachment period (24 August), we recaptured all individuals and determined initial body mass $(\mathrm{g})$, wing chord $(\mathrm{mm})$, and tarsus length (mm). We also attached 0.7-g transmitters (SOPB 2011, Wildlife Materials Inc., Carbondale, Illinois) to half $(n=5)$ of the birds using the Rappole and Tipton (1991) harness and attachment method. Control birds were also briefly equipped with transmitters to control for possible effects of capturing and handling. We constructed the harness using elastic cotton beading cord, and used super glue (Duro, Avon, Ohio) to secure knots on the transmitter. To control for possible effects of capture and handling, we removed transmitters from control birds prior to exiting the pen. From 24 August to 20 September, we collected postattachment fecal samples every other day for 14, 24-hr collection periods. On 20 September 2001, all individuals were recaptured, transmitters were removed, and final body mass (g) was measured for all individuals. The birds were then transported to their original capture sites and released.

\section{FECAL SAMPLE PROCESSING}

Frozen fecal samples were placed in a lyophilizer (Freeze-dry Specialties, Inc., Osseo, Minnesota) for 24 hr. Once freeze dried, samples were ground and sifted through U.S. standard number 25 stainless steel mesh. Fecal glucocorticoid metabolites were extracted from feces using a modification of Schwarzenberger et al. (1991). Dried feces $(\sim 0.2 \mathrm{~g})$ were placed in a test tube with $2.0 \mathrm{~mL}$ of $90 \%$ methanol and vortexed at high speed in a multitube vortexer for $30 \mathrm{~min}$. Samples were then centrifuged at $500 \mathrm{~g}$ for $20 \mathrm{~min}$, and the supernatant was saved and stored at $-84^{\circ} \mathrm{C}$ until assayed.

\section{FECAL GLUCOCORTICOID ANALYSES}

We used corticosterone ${ }^{125}$ radioimmunoassay (RIA) kits (ICN \#07-120103, ICN Biomedicals, Costa Mesa, California) to quantify Dickcissel fecal glucocorticoid metabolite concentrations. Fecal samples were analyzed in four assays, with each assay including all the samples from an individual bird. We followed the ICN protocol for the corticosterone ${ }^{125}$ RIA, except that we halved the volume of all reagents (Wasser et al. 2000). We validated the fecal glucocorticoid metabolite assay for Dickcissels using validation procedures (Grotjan and Keel 1996, O'Fegan 2000), which included demonstration of parallelism, recovery of exogenous analyte, precision, accuracy, and lack of sample matrix effects. We conducted parallelism and recovery of exogenous corticosterone validation assays on two pooled fecal extract samples (low and high; each pool consisted of feces from five individuals). Parallelism ensures the assay maintains linearity under dilution, 
and recovery of exogenous corticosterone verifies accurate measurement throughout the working range of the assay (Jeffcoate 1981). Based on the results of the parallelism dilutions, we diluted all fecal sample extracts to 1:4 with steroid dilutent prior to assay. We randomly selected three Dickcissel fecal samples and analyzed them in each assay; interassay variation was calculated from these three samples. Intra-assay variation was calculated by averaging the CVs of replicate tubes from 20 randomly chosen samples.

\section{STATISTICAL ANALYSIS}

To compare fecal glucocorticoid levels during preattachment (periods 1-11) and postattachment (periods 12-25) treatments, we created a new data set using preattachment means for each bird and the subsequent change in fecal glucocorticoids for each period after attachment. This procedure allowed us to use fecal glucocorticoid levels from each bird as its own control to generate baseline values for later comparison with postattachment levels. We visually inspected our data for normality using quantile plots (Sokal and Rohlf 1995) and were satisfied that the assumption of normality was met.

We performed a two-way, repeated measures ANOVA using a completely randomized split-plot design to test differences in fecal glucocorticoids between treatments and across periods (Littell et al. 1996). We used individual birds as the experimental unit and treated them as random effects in the analysis to enable inferences about the entire population (Littell et al. 1996). Both the treatment (between-subjects) and period (within-subjects) factors were considered fixed effects. We used PROC MIXED in SAS (SAS Institute Inc. 1999) to model the covariance structure and ensure correct calculation of standard errors (SAS Institute Inc. 1997, Littell et al. 1998). We fit three covariance structures based on recommendations from Littell et al. $(1996,1998)$ including the compound symmetry, unstructured, and autoregressive covariance structures. We used Akaike's Information Criterion for small samples $\left(\mathrm{AIC}_{c}\right)$ to select the best model for the covariance structure. Differences were considered significant at $P$ $=0.05$. When results of the repeated measures ANOVA were significant, we performed multiple comparisons using Bonferroni adjustments (Sokal and Rohlf 1995). We used linear regression to determine whether air temperature was related to fecal glucocorticoid levels. We used independent, two-tailed $t$-tests to compare mean body condition (initial, final, and weight change) and morphology (wing chord and tarsus length) between control and transmitter birds. Results are presented as means $\pm \mathrm{SE}$.

\section{RESULTS}

\section{RADIOIMMUNOASSAY VALIDATION}

Given the satisfactory performance characteristics of the assay, we determined fecal glucocorticoid assay validation was successful for Dickcissels. Serial dilutions (1:2 up to $1: 128$; using steroid dilutent) of Dickcissel fecal extracts yielded displacement curves that were parallel (all $P>0.6$ ) to the corticosterone standard curve (Fig. 1). Mean recovery of added exogenous corticosterone (range $0.5-1.25 \mathrm{ng} \mathrm{mL}^{-1}$ ) was 105

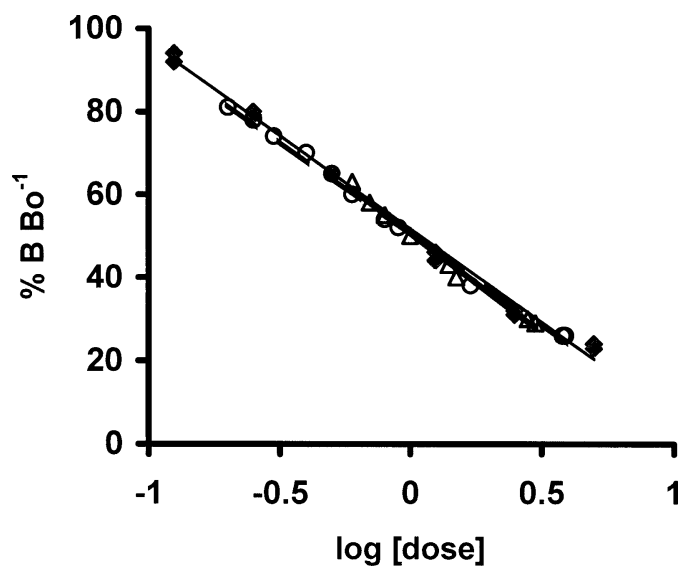

FIGURE 1. Parallelism of fecal glucocorticoid metabolite results for fecal extracts from Dickcissels in Missouri. Curves of percent binding of $\mathrm{I}^{125}$ tracer $(\% \mathrm{~B}$ $\mathrm{B}_{\mathrm{o}}{ }^{-1}$ ) versus serially diluted (log-transformed doses of $1: 2$ to $1: 128)$ low pool $(n=2)$ and high pool $(n=2)$ fecal extracts from male wild Dickcissels in captivity were parallel to corticosterone standard curves (logtransformed doses of 0.125 to $5.0 \mathrm{ng} \mathrm{mL}^{-1}$; test of equal slopes, all $P>0.6$ ). Corticosterone standard curve points are represented by diamonds, points from serially diluted low pool fecal extracts are represented by circles, and points from serially diluted high pool fecal extracts are represented by triangles.

$\pm 2.9 \%(n=12)$. Acceptable recovery of exogenous analyte (within 90-110\%) and demonstration of parallelism suggests no sample matrix effects (Jeffcoate 1981, Grotjan and Keel 1996, O'Fegan 2000). Assay sensitivity was $1.25 \mathrm{ng} \mathrm{g}^{-1}$. The manufacturer's reported cross-reactivity of the antisera was $100 \%$ with corticosterone and $<1 \%$ for other steroids. Interassay variation for four assays was $8.8 \%$ and average intraassay variation was $1.8 \%$.

\section{TRANSMITTER EFFECTS}

We captured 10 male Dickcissels from 29 June to 15 July 2001. Body condition (initial, final, and change in weight) and morphology (wing chord and tarsus length) were similar between control and transmitter birds (all $t_{8} \leq 1.0$, all $P \geq 0.2$; Table 1). Although wing chord measurements and plumage variations described by Pyle (1997) did not allow conclusive identification of hatch-year from second-year males, subsequent radio-telemetry work with postfledging Dickcissels and the observation of paired males displaying territorial behavior prior to capture suggest birds were likely second-year males (KSW, unpubl. data).

Results from fitting three covariance structures indicated the autoregressive structure provided the best fit, as shown by the lowest $\mathrm{AIC}_{c}$ score. $\mathrm{AIC}_{c}$ scores for the covariance structures were 1199.0 for compound symmetry and 1193.1 for the autoregressive structure. Results from fitting an unstructured model were not successful because it was computationally extensive (Littell et al. 1998) and exhausted all degrees of free- 
TABLE 1. Measurements of 10 male Dickcissels captured in central Missouri during the summer of 2001: initial body mass $(\mathrm{g})$ at the time of transmitter attachment (after acclimation period), final mass $(\mathrm{g})$, mass change $(\mathrm{g})$, wing chord $(\mathrm{mm})$, and tarsus length $(\mathrm{mm})$. Means between control and transmitter-equipped birds were not different for any of the body condition or morphology variables measured (all $t_{8} \leq 1.0, P>0.2$ ).

\begin{tabular}{|c|c|c|c|c|c|}
\hline Bird ID & $\begin{array}{l}\text { Initial } \\
\text { mass }(\mathrm{g})\end{array}$ & $\begin{array}{c}\text { Final } \\
\text { mass (g) }\end{array}$ & $\begin{array}{c}\text { Mass } \\
\text { change }(\mathrm{g})\end{array}$ & $\begin{array}{c}\text { Wing } \\
\text { length (mm) }\end{array}$ & $\begin{array}{c}\text { Tarsus } \\
\text { length }(\mathrm{mm})\end{array}$ \\
\hline \multicolumn{6}{|l|}{ Control birds } \\
\hline 25 & 28 & 38 & +10 & 79 & 24 \\
\hline 27 & 31 & 40 & +9 & 81 & 25 \\
\hline 29 & 29 & 39 & +10 & 81 & 23 \\
\hline 31 & 28 & 35 & +7 & 83 & 25 \\
\hline 34 & 33 & 43 & +10 & 80 & 25 \\
\hline Mean $\pm \mathrm{SE}$ & $29.8 \pm 1.0$ & $39.0 \pm 1.3$ & $+9.2 \pm 0.8$ & $80.8 \pm 0.7$ & $24.4 \pm 0.4$ \\
\hline \multicolumn{6}{|c|}{ Transmitter-equipped birds } \\
\hline 26 & 30 & 29 & -1 & 83 & 23 \\
\hline 28 & 27 & 34 & +7 & 79 & 24 \\
\hline 30 & 29 & 39 & +10 & 80 & 24 \\
\hline 32 & 30 & 39 & +9 & 79 & 25 \\
\hline 35 & 34 & 41 & +7 & 81 & 25 \\
\hline Mean $\pm \mathrm{SE}$ & $30.0 \pm 1.4$ & $36.4 \pm 2.2$ & $+6.4 \pm 1.9$ & $80.4 \pm 0.8$ & $24.4 \pm 0.2$ \\
\hline
\end{tabular}

dom. There was a significant interaction between transmitter treatment and time since attachment $\left(F_{14.112}=\right.$ 2.8, $P<0.01$; Fig. 2). Compared to baseline levels (pretreatment), changes in fecal glucocorticoid levels in the control group were not higher following capture and handling $24 \mathrm{hr}\left(F_{14,112}=0.5, P>0.6\right)$ or $48 \mathrm{hr}$ after attachment $\left(F_{14,112}=0.3, P>0.7\right.$; Fig. 2$)$. Conversely, the change in fecal glucocorticoid levels in the transmitter group was substantially higher during the first $24 \mathrm{hr}$ after attachment $\left(F_{14,112}=7.5, P<0.01\right)$, but not thereafter (Fig. 2). Mean change in fecal glucocorticoid levels in the control group $24 \mathrm{hr}$ after capture and handling was $6.1 \pm 13.7 \mathrm{ng} \mathrm{g}^{-1}$ compared to $102.3 \pm 13.7 \mathrm{ng} \mathrm{g}^{-1}$ in the transmitter group. Maximum air temperature did not explain a significant pro- portion of the variability in fecal glucocorticoids in control $\left(r^{2}=0.03, F_{1.12}, P>0.4\right)$ or transmitter $\left(r^{2}=\right.$ $\left.0.08, F_{1,12}, P>0.3\right)$ birds during the postattachment period (periods 12-25).

\section{DISCUSSION}

We have shown that captive Dickcissels fitted with transmitters exhibited an acute increase in fecal glucocorticoid levels during the first $24 \mathrm{hr}$ after attachment. However, the effect was short lived and fecal glucocorticoid levels returned to baseline levels within approximately $48 \mathrm{hr}$ after attachment. Our results are important because they support the assumption that radio-transmitters do not have persistent effects. Although more research is needed, we suggest radio-

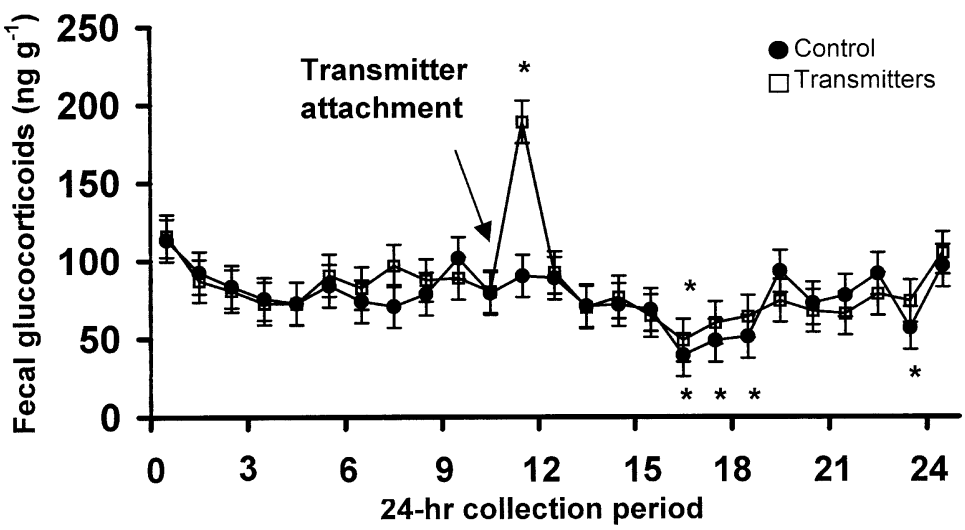

FIGURE 2. Fecal glucocorticoid metabolite levels $\left(\mathrm{ng}^{-1}\right)$ of male hatch-year/second-year Dickcissels in Missouri in control (filled circles; $n=5$ ) and transmitter-equipped (unfilled squares; $n=5$ ) groups during preattachment (periods 1-11) and postattachment (periods 12-25). Each period represents a 24-hr collection interval. Significant differences between preattachment and postattachment fecal glucocorticoid levels for each 24-hr period are denoted with asterisks. 
transmitters are a viable option for assessing space use in small birds.

Although a few published studies document the physiological effects of transmitters on game birds (Schulz et al. 1998, 2001), our study is the first to our knowledge to report physiological effects of transmitters on passerines. Effects of transmitters on Greater Prairie-Chickens (Tympanuchus cupido) and Mallards (Anas platyrhynchos), include decreased survival (both species; Burger et al. 1991, Paquette et al. 1997), reduced feeding, increased resting, and decreased reproductive output (Mallards; Pietz et al. 1993). Similar investigations with passerines have shown a reduction in foraging bouts (Brigham 1989), shortened migration distances (Powell et al. 1998), increased preening time, increased number of flights, and weight loss (Sykes et al. 1990); yet all the studies have concluded that transmitters have minimal to negligible effects. However, without linking behavioral indications with demographic impacts, such as survival and reproduction, researchers may not detect an effect.

Our results showed more than a 15 -fold increase from baseline in fecal glucocorticoids for birds with transmitters compared to no statistically significant increase in control birds $24 \mathrm{hr}$ after attachment. However, at least two factors might confound our interpretation of this result as a transmitter effect. Maximum air temperatures spiked sharply from $31^{\circ} \mathrm{C}$ to $37^{\circ} \mathrm{C}$ (Columbia Regional Airport, Ashland, Missouri) during the last preattachment period (period 11), and could have accentuated the stress response due to attachment. However, maximum temperature was not correlated with the increase in fecal glucocorticoids in transmitter-equipped birds during the first postattachment period. Our results are consistent with those of Wingfield et al. (1992), which showed plasma levels of corticosterone in birds of the Sonoran Desert were not elevated during extreme summer temperatures (averaging $40.2^{\circ} \mathrm{C}$ in July).

The potential mixing of hatch-year and second-year males in our sample could also confound our interpretation of the stress response. If our sample contained HY males, then trends in individual variability of stress levels, body condition, and morphology may have been a result of different age classes. For example, our preliminary work using radio-telemetry with postfledging Dickcissels and other passerine work (Vega Rivera, Rappole, et al. 1998, Vega Rivera, McShea, et al. 1998) indicate hatch-year birds might show different patterns of habitat use and movement during the postfledging period compared to adults. Although we are not aware of any data describing differences in the timing of molt and migration between age groups for this species, Vega Rivera, McShea, et al. (1998) described such differences for Wood Thrush (Hylocichla mustelina). Mixing age groups in our sample might have contributed to the trend (nonsignificant) for transmitter-equipped birds to gain less mass than control birds, but only one bird lost weight in captivity. Future studies that replicate our design with larger sample sizes on uniform age groups are needed.

Radio-transmitters and the attachment technique we used (Rappole and Tipton 1991) are a viable option for assessing space use in small passerines. However, researchers using radio-telemetry should be aware that stress responses associated with capture, handling, and radio-transmitter attachment can influence birds in subtle ways (i.e., behaviorally, physiologically). Noninvasive physiological assessments, such as fecal glucocorticoid metabolite analysis, show promise for addressing such subtle effects.

We thank two anonymous reviewers and D. Dobkin for comments that improved the manuscript. Funding was provided by the University of Missouri and the Missouri Department of Conservation Natural History Division. M. Wahlendorf and M. Ellersieck provided statistical advice. J. Wells and T. Mong assisted with cage construction and data collection. This research was approved by the University of Missouri Animal Care and Use Committee (Protocol \#3643).

\section{LITERATURE CITED}

BRIGHAM, R. M. 1989. Effects of radio transmitters on the foraging behavior of Barn Swallows. Wilson Bulletin 101:505-506.

Burger, L. W., M. R. Ryan, D. P. Jones, and A. P. WYWIALOWSKI. 1991. Radio transmitters bias estimation of movements and survival. Journal of Wildlife Management 55:693-697.

Grotjan, H. E., And B. A. Keel. 1996. Data interpretation and quality control, p. 51-93. In E. P. Diamandis and T. K. Christopoulos [EDS.], Immunoassay. Academic Press, New York.

Hiebert, S. M., M. Ramenofsky, K. Salvante, J. C. WingField, AND C. L. Gass. 2000. Noninvasive methods for measuring and manipulating corticosterone in hummingbirds. General and Comparative Endrocrinology 120:235-247.

JefFCOATE, S. L. 1981. Efficiency and effectiveness in the endocrinology laboratory. Academic Press, New York.

Kernohan, B. J., R. A. Gitzen, and J. J. Millspaugh. 2001. Analysis of animal space use and movements, p. 126-168. In J. J. Millspaugh and J. M. Marzluff [EDS.], Wildlife radiotelemetry: design and analysis. Academic Press, San Diego, CA.

Le Maho, Y., H. Karmann, D. Briot, and Y. HanDRICH. 1992. Stress in birds due to routine handling and a technique to avoid it. American Journal of Physiology 263:775-781.

Littell, R. C., P. R. Henry, and C. B. Ammerman. 1998. Statistical analysis of repeated measures data using SAS procedures. Journal of Animal Science 76:1216-1231.

Littell, R. C., G. A. Milliken, W. W. Stroup, and R. D. Wolfinger. 1996. SAS system for mixed models. SAS Institute, Cary, NC.

Neudorf, D. L., AND T. E. PITCHER. 1997. Radio transmitters do not affect nestling feeding rates by female Hooded Warblers. Journal of Field Ornithology 68:64-68.

O'Fegan, P. O. 2000. Validation, p. 211-238. In J. P. Gosling [ED.], Immunoassays. Oxford University Press, New York.

Paquette, G. A., J. H. Devries, R. B. Emery, D. W. Howerter, B. L. JoYnt, AND T. P. SANKOWSKI. 1997. Effects of transmitters on reproduction and 
survival of wild Mallards. Journal of Wildlife Management 61:953-961.

Pietz, P. J., G. L. Krapu, R. J. Greenwood, and J. T. LOKEMOEN. 1993. Effects of harness transmitters on behavior and reproduction of wild Mallards. Journal of Wildlife Management 57:696-703.

Powell, L. A., D. G. Krementz, J. D. Lang, And M. J. ConRoy. 1998. Effects of radio transmitters on migrating Wood Thrushes. Journal of Field Ornithology 69:306-315.

PyLE, P. 1997. Identification guide to North American birds. Slate Creek Press, Bolinas, CA.

Rappole, J. H., And A. R. Tipton. 1991. New harness design for attachment of radio transmitters to small passerines. Journal of Field Ornithology 62: 335-337.

SAPolsky, R. M., L. M. Romero, and A. U. Munck. 2000. How do glucocorticoids influence stress responses? Integrating permissive, suppressive, stimulatory, and preparative actions. Endocrine Reviews 21:55-89.

SAS InstituTE INC. 1997. SAS/STAT software: changes and enhancements through release 6.12. SAS Institute Inc., Cary, NC.

SAS InstituTE InC. 1999. SAS user's guide: statistics, version 8.0. SAS Institute Inc., Cary, NC.

Schulz, J. H., A. J. Bermudez, J. L. Tomlinson, J. D. FIRMAN, AND Z. HE. 1998. Effects of implanted radiotransmitters on captive Mourning Doves. Journal of Wildlife Management 62:1451-1460.

Schulz, J. H., A. J. Bermudez, J. L. Tomlinson, J. D. FIRMAN, AND Z. HE. 2001. Comparison of radiotransmitter attachment techniques using captive Mourning Doves. Wildlife Society Bulletin 29: $771-782$.

Schwarzenberger, F., E. Möstl, E. Bamberg, J. PamMER, AND O. SCHMEHLIK. 1991. Concentrations of progestagens and oestrogens in the feces of pregnant Lipizzan, trotter and thoroughbred mares. Journal of Reproduction and Fertility Supplement 44:489-499.

Sokal, R. R., AND F. J. Rohlf. 1995. Biometry. 3rd ed. W. H. Freeman and Company, New York.
Sykes, P. W., Jr., J. W. Carpenter, S. Holzman, and P. H. GeISSLER. 1990. Evaluation of three miniature radio transmitter attachment methods for small passerines. Wildlife Society Bulletin 18:4148.

Vega Rivera, J. H., W. J. McShea, J. H. Rappole, AND C. A. HAAS. 1998. Pattern and chronology of prebasic molt for the Wood Thrush and its relation to reproduction and migration departure. Wilson Bulletin 110:384-392.

Vega Rivera, J. H., J. H. Rappole, W. J. McShea, AND C. A. HAAS. 1998. Wood Thrush postfledgling movements and habitat use in northern Virginia. Condor 100:69-78.

Wasser, S. K., K. E. Hunt, J. L. Brown, K. Cooper, C. M. Crockett, U. Bechert, J. J. Millspaugh, S. Larson, and S. L. Monfort. 2000. A generalized fecal glucocorticoid assay for use in a diverse array of nondomestic mammalian and avian species. General and Comparative Endocrinology 120:260-275.

Washburn, B. E., D. L. Morris, J. J. Millspaugh, J. FAABORG, AND J. H. Schulz. 2002. Using a commercially available radioimmunoassay to quantify corticosterone in avian plasma. Condor 104:558563.

White, G. C., And R. A. Garrott. 1990. Analysis of wildlife radio-tracking data. Academic Press, San Diego, CA.

Wingfield, J. C., D. L. Maney, C. W. Breuner, J. D. JACOBS, S. LYNN, M. RAMENOFSKY, AND R. D. RICHARDSON. 1998. Ecological basis of hormonebehavior interactions: the "emergency life history stage." American Zoologist 38:191-206.

Wingfield, J. C., C. M. Vleck, And M. C. Moore. 1992. Seasonal changes of the adrenocortical response to stress in birds of the Sonoran Desert. Journal of Experimental Zoology 264:419-428.

Withey, J. C., T. D. Bloxton, And J. M. Marzluff. 2001. Effects of tagging and location error in wildlife telemetry studies, p. 43-75. In J. J. Millspaugh and J. M. Marzluff [EDS.], Radio tracking and animal populations. Academic Press, New York. 